Die variablen Produktionskosten werden durch mehrere Merkmale der Mastleistung erfasst. Die variable Erlöskomponente und die variablen Produktionskosten werden zu einem Index für die Produktionsleistung zusammengefasst. Die variablen Reproduktionskosten ergeben sich aus den durchschnittlichen Sauenhaltungskosten, die von der Anzahl der aufgezogenen Ferkel je Jarhr ahbängen. Spezielle Gewinnfunktionen für verschiedene Formen von Gebrauchskreuzungen werden abgeleitet.

1. bei ausschliesslicher Annahme von additiver Genwirkung.

2. bei Annahme von additiver Genwirkung und durchschnittlicher Heterosiseffekte.

3. bei Annahme von additiver Genwirkung und durchschnittlicher Heterosiseffekte unter Einbeziehung der Nebenproduktion/Mastschweine in Vermehrungsbetrieben.

Anhand von Gewinnfunktionen werden Modellrechnungen über die Effektivität verschiedener Formen von Gebrauchskreuzungen durchgeführt. Als Ausgangspopulationen wurden 9 Zuchtlinien mit unterschiedlicher Produktions-und Reproduktionsleistung unterstellt, dahei wurde angenommen. dass zwischen der Fleischleistung und der Aufzuchtleistung negative Beziehungen bestehen. Für die verschiedenen Komponenten der Heterosiswirkung wurden durchsschnittliche Heterosiseffekte unterstellt.

Die wichtigsten Ergebnisse der Modellrechnungen sind :

1. Die Produktionsleistung der Ausgangslinien wirkt sich in viel stärkerem Ausmass auf die Rentabilität der Schweineproduktion bei Gebrauchskreuzungen aus als die Reproduktionsleistung.

2. Überragt eine Zuchtlinie alle anderen in der Produktionsleistung wesentlich, so kann durch Reinzucht mit dieser Zuchtlinie der höchste Gewinn erzielt werden.

Sofern verlässliche Informationen über das Leistungsniveau der vorhandenen Zuchtlinien zur Verfügung stehen, sollte eine Vorauswahl erfolgversprechender Zuchtlinien für die anschliessende Leistungsprüfung mit Hilfe von Gewinnfunktionen vorgenommen werden.

\title{
Results OF CROSSBREEding PIGS IN Czechoslovakia
}

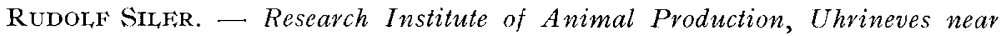 \\ Prague, Czechoslovakia.
}

Crossbreeding pigs is now a common practice in C\%echoslovakia as compared with the situation 10-12 years ago. There are two native breeds, $i$. e. Czech Large White (CLW), and Black Spotted Prestice (BSP), and three imported breeds, i. e. Land-race (L), Large Black $(L B)$, and Piétrain $(P) .57$ per cent of the total number of boars are used for commercial crossbreeding. The most popular combination is $C L W \times L B$. The use of this combination is decreasing in recent years in favour of crossing $C L W$ dams with $L$ boars.

As regards research work only mentioning results from recent years, an experiment with reciprocal crossing including $C L W, L, L B, B S P$, and $P$ was completed. No maternal effects and no significant differences between the reciprocal crosses were found. The amount of heterosis for various characters was also estimated. The largest heterotic effect was in reproductive characters $(7-10 \%)$; a medium one in fattening ahility $(2-4 \%$ ) was found, and none in carcass value.

$L$ boars are mostly used for improvement of $C L W$ meat quality. The crossbred plogeny shows a better carcass quality than purebred $C L W$. Results of a special experiment indicated that it is best to fatten these crossbreds to a weight of $100-110 \mathrm{kgs}$.

The performance of crossbreds from crossbreeding, criss-crossbreeding, and rotational crossbreeding was evaluated by using $C L W, L$, and $L B$. As regards litter size, the combination $(C L W \times L) \times L B$ was found to be the most effective one.

The general possibilities of predicting the efficiency of crossbreds on the basis of knowledge at the original parental populations were also examined, and contemporaneous views regarding the evaluation of heterotic effect were evaluated. 